\title{
Pengembangan Website Informasi Sekolah di SMP Negeri 2 Kalimanah, Purbalingga
}

\author{
Yogiek Indra Kurniawan ${ }^{1 *}$, Nur Chasanah ${ }^{1}$, Nofiyati ${ }^{1}$ \\ ${ }^{1}$ Informatika, Fakultas Teknik, Universitas Jenderal Soedirman, Jalan Mayor Jenderal Sungkono KM 5, \\ Purbalingga, Jawa Tengah, Indonesia 53371 \\ *Email Korespondensi: yogiek@unsoed.ac.id
}

\begin{abstract}
Abstrak
Sekolah Menengah Pertama Negeri (SMP N) 2 Kalimanah adalah sebuah sekolah lanjutan pertama yang berada di daerah Kalimanah, Purbalingga, Jawa Tengah. Berdasarkan observasi serta wawancara yang telah dilakukan, terdapat permasalahan di Sekolah tersebut, yaitu mengenai promosi dan penyebaran informasi ke luar sekolah yang masih sangat kurang dikarenakan pada saat ini hanya terfokus pada poster dan majalah dinding. Tujuan dari kegiatan ini adalah dengan membuat sebuah website informasi sekolah yang khusus menampilkan informasi-informasi untuk SMP N 2 Kalimanah kemudian memberikan pelatihan kepada para guru untuk dapat mengisi website tersebut ke depannya. Dengan adanya website, maka pihak sekolah dapat terhubung secara lebih mudah dengan pihak di luar sekolah karena website tersebut dapat diakses oleh setiap orang dimanapun dan kapanpun asal terhubung dengan koneksi internet. Kegiatan pengabdian terbagi menjadi beberapa tahap, yaitu need assessment, implementasi aplikasi, pemaparan dan pelatihan website kepada guru, serta simulasi dan pengujian. Hasil kegiatan ini adalah sebuah website informasi sekolah di SMP N 2 Kalimanah yang dapat menampilkan berita, foto, dan kegiatan-kegiatan di lingkungan sekolah kepada masyarakat luas. Selain itu, berdasarkan pengujian User Acceptance Test yang telah dilakukan, 95\% responden menyatakan bahwa website informasi sekolah telah berhasil menyelesaikan permasalahan promosi dan penyampaian berita di SMP N 2 Kalimanah.
\end{abstract}

Kata kunci: Promosi; sekolah; website

\begin{abstract}
Sekolah Menengah Pertama Negeri (SMP N) 2 Kalimanah is a secondary school located in the Kalimanah area, Purbalingga, Central Java. Based on observations and interviews that have been conducted, there are problems at the school, namely regarding the promotion and dissemination of information outside the school which is still lacking because at this time it is only focused on posters and wall magazines. The aims of this activity are to create a school information website that specifically displays information for SMP N 2 Kalimanah then provides training for teachers to be able to fill in the website in the future. With the website, the school can connect more easily with parties outside the school because the website can be accessed by everyone anywhere and anytime as long as it is connected to an internet connection. The service activities are divided into several stages, namely need assessment, application implementation, presentation and website training to teachers, as well as simulation and testing. The result of this activity is a school information website at SMP N 2 Kalimanah that can display news, photos, and activities in the school environment to the wider community. In addition, based on the User Acceptance Test that have been carried out, 95\% of respondents stated that the school information website had succeeded in solving the problems of promotion and news delivery at SMP N 2 Kalimanah.
\end{abstract}

Keywords: Promotion; school; website

Format Sitasi: Kurniawan, Y.I., Chasanah, N., \& Nofiyati. (2020). Pengembangan Website Informasi Sekolah di SMP Negeri 2 Kalimanah Purbalingga. Jurnal Solma, 09(2), 335-346. Doi: http://dx.doi.org/10.22236/solma.v9i2.5440

Diterima: 23 Agustus 2020 | Revisi 8 September 2020 | Dipublikasikan: 30 Oktober 2020


(C) 2020 Oleh authors. Lisensi Jurnal Solma, LPPM-Uhamka, Jakarta. Artikel ini bersifat open access yang didistribusikan di bawah syarat dan ketentuan Creative Commons Attribution (CC BY) license. (http://creativecommons.org/licenses/by/4.0/).

\section{PENDAHULUAN}

Hadirnya teknologi jaringan internet yang dapat menghubungkan seluruh node (perangkat komputer) yang ada di dunia ini menjadikan lahirnya alternative baru untuk menyampaikan informasi dengan lebih luas serta tanpa batasan waktu dan tempat. Salah satunya teknologi yang dapat melakukan hal tersebut adalah website, yang memungkinkan situs ditampilkan dalam bentuk digital dan dapat diakses dimanapun dan kapanpun sebagai sebuah node yang terhubung ke internet. Website juga dapat digunakan untuk berbagai pengolahan data yang penting bagi sebuah institusi (Haris et al., 2019)

Banyak sekali manfaat yang dapat diberikan website untuk sekolah, antara lain : website dapat meningkatkan mutu layanan sekolah, serta terciptanya komunikasi yang efektif, cepat, dan akurat antara pihak sekolah, siswa, dan wali murid (Azizah \& Saputro, 2020). Website juga dapat memberikan informasi lebih luas kepada masyarakat mengenai profile (Wulandari \& Dewi, 2019). Selain itu, website dapat mempermudah manajemen SDM pada sekolah (Tentua \& Saputra, 2020) serta dapat juga digunakan sebagai sarana dalam pembelajaran di sekolah (Wiryotinoyo et al., 2020).

Paper (Sholikat et al., 2019) menunjukkan bahwa website yang berbasis video pun dapat memperkenalkan dan mempromosikan sekolah dengan lebih baik. Selain itu, pembangunan website sekolah dapat dilakukan dengan Content Management Systems(CMS) secara lebih mudah (Lubis et al., 2020). Contoh CMS yang dapat digunakan untuk membuat website antara lain Wordpress dan juga Blogspot.

Berdasarkan uraian di atas, dapat diketahui bahwa website dapat memberikan banyak manfaat untuk sekolah. Website menjadi sebuah alat yang penting bagi sekolah di era teknologi saat ini. Hanya saja, beberapa sekolah belum memiliki website resmi sebagai sarana penyebaran informasi maupun promosi. Salah satunya sekolah yang belum memiliki website sekolah tersebut adalah SMP Negeri 2 Kalimanah di Purbalingga.

Tujuan kegiatan ini adalah untuk membantu SMP Negeri 2 Kalimanah dalam membuat website informasi sekolah yang dapat menyebarkan informasi serta sebagai sarana promosi bagi sekolah. Dengan adanya website tersebut, maka pihak sekolah dapat terhubung secara lebih mudah dengan pihak di luar sekolah karena website tersebut dapat diakses oleh setiap orang dimanapun dan kapanpun asal terhubung dengan koneksi internet.

\section{MASALAH}

Sekolah Menengah Pertama Negeri (SMP N) 2 Kalimanah adalah sebuah sekolah menengah tingkat pertama yang berada di daerah Kalimanah, Purbalingga, Jawa Tengah yang terletak di Jalan Mayor Jendral Sungkono km. 3 Desa kalimanah Wetan Kabupaten Purbalingga. Sekolah ini menampung siswa yang umumnya berada di sekitar daerah tersebut.

SMPN 2 Kalimanah saat ini telah mengalami kemajuan yang pesat. Mulai dari fisik bangunan, fasilitas pendidikan yang memadai, halaman parkir yang luas, serta penunjang sistem pembelajaran di sekolahan ini. Jumlah peserta didik di sekolah ini termasuk dalam 
golongan banyak, yaitu 756 siswa yang terbagi dalam 3 angkatan, yaitu kelas 7, kelas 8 dan kelas 9, dengan rata-rata setiap angkatan adalah sebanyak 250 siswa. Sekolah ini mempunyai keunggulan di banding sekolahan yang lain mulai dari penunjang pendidikan yang semakin ditingkatkan seperti laboratorium, sarana olahraga, dan perpustakaan. Luas lahan sekolah sebesar $9.840 \mathrm{~m}^{2}$ menjadikan sekolah ini mencukupi untuk kegiatan pendidikan siswanya.

Berdasarkan hasil observasi di lingkungan sekolah dan wawancara dengan kepala sekolah SMP N 2 Kalimanah, diperoleh informasi bahwa sekolah ini merupakan salah satu sekolah yang cukup berkembang di daerah Kalimanah, Purbalingga, dengan dibuktikan jumlah siswa yang terus meningkat. Faktor pendukung yang masih kurang di SMP ini adalah sekolah saat ini belum memiliki web aktif, sehingga informasi mengenai sekolah belum mudah diakses masyarakat, demikian halnya dalam memberikan informasi tentang penerimaan siswa baru, masih dilakukan dengan penyebaran poster di wilayah sekitar maupun di lingkup sekolah, sehingga kurang efektif dalam menjaring calon siswa yang potensial.

Pada tanggal 1 Mei 2020, dilakukan percobaan dengan mencari informasi mengenai SMP N 2 Kalimanah di mesin pencarian google. Gambar 1 menunjukkan hasil pencarian dari mesin pencari Google mengenai SMP N 2 Kalimanah.

Hasil pencarian dari Google tersebut memperlihatkan bahwa hasilnya hanya berupa data dari kemendikbud, sebuah blog serta informasi dari berita-berita online. Masyarakat yang ingin mengetahui mengenai informasi tentang sekolah tersebut kemungkinan besar tidak bisa mendapatkan informasi mengenai SMP N 2 Kalimanah.

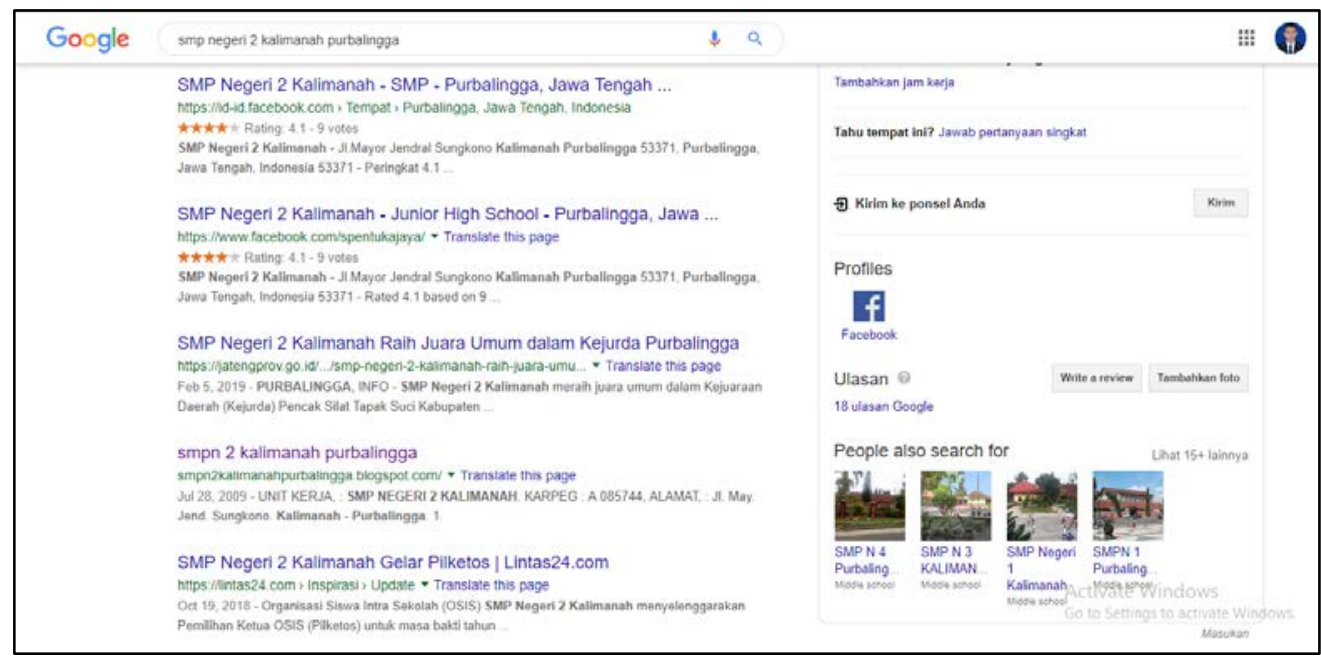

Gambar 1. Hasil Pencarian SMP N 2 Kalimanah di Mesin Pencari Google

Pada saat dilakukan penelusuran lebih lanjut terhadap blog SMP N 2 Kalimanah, hanya terdapat 3 buah post/berita yang ketiganya hanya berisi biodata 3 guru saja. Website atau blog ini tidak bisa menggambarkan keadaan tentang SMP N 2 Kalimanah dengan baik. Tampilan maupun isi konten dari website tersebut juga tidak bisa menjadi sarana promosi untuk masyarakat luar. Gambar 2 menunjukkan tampilan dari Blog SMP N 2 Kalimanah. 


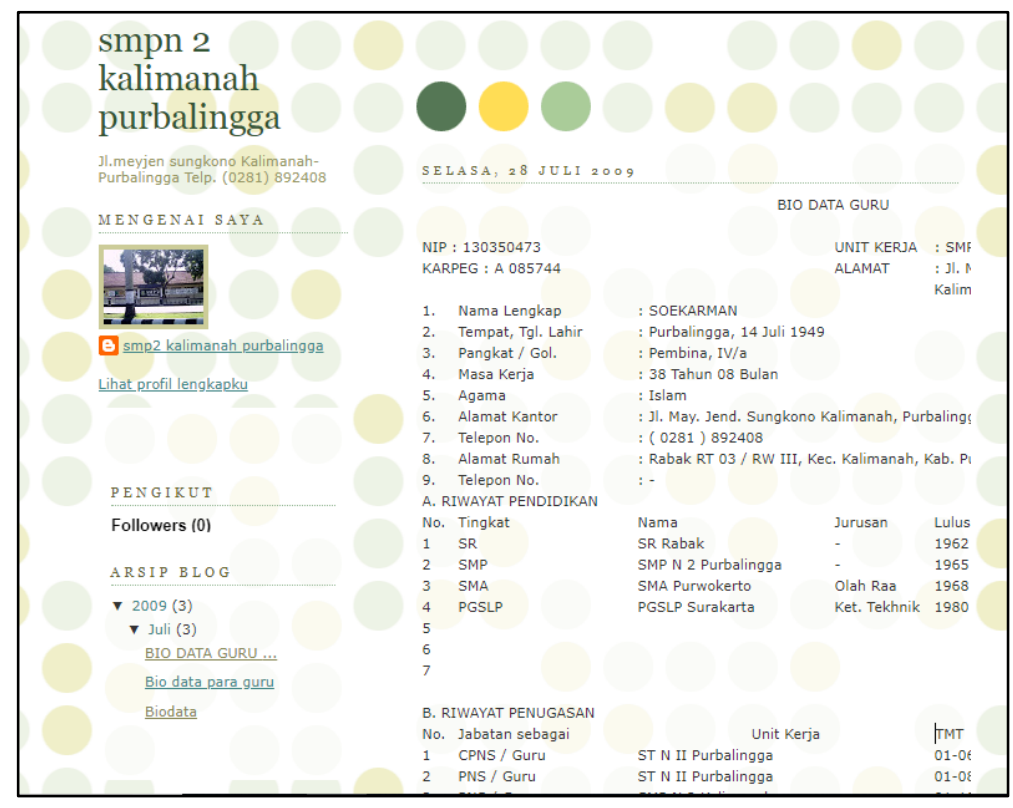

Gambar 2. Blog SMP N 2 Kalimanah

Berdasarkan uraian data dan fakta di atas, dapat dipaparkan beberapa permasalahan di SMP N 2 Kalimanah, yaitu:

1. Promosi penerimaan siswa baru di SMP Negeri 2 Kalimanah belum maksimal, hanya dilakukan dengan menyebar poster. Informasi yang diberikan sangat kurang, sehingga calon peserta didik masih harus mengakses langsung ke sekolah.

2. Pihak sekolah memiliki kendala dalam penyampaian informasi ke pihak luar (stake holders) terkait : kondisi di SMP N 2 Kalimanah, kegiatan-kegiatan yang dilangsungkan di sekolah, materi pembelajaran untuk siswa, berita terkini yang terjadi di sekolah, info Penerimaan Peserta Didik Baru (PPDB), maupun informasi yang lainnya.

\section{METODE PELAKSANAAN}

Berdasarkan permasalahan di SMP N 2 Kalimanah, solusi yang ditawarkan untuk mengatasi permasalahan mengenai promosi yang belum maksimal dan kendala dalam penyampaian informasi ke pihak luar di SMP N 2 Kalimanah adalah dengan memfasilitasi pembuatan website informasi sekolah yang khusus menampilkan informasi-informasi untuk SMP N 2 Kalimanah dikarenakan sekolah ini belum memiliki website resmi yang menampilkan informasi di sekolahnya. Website menjadi sebuah alternatif baru dalam segala bidang, salah satunya ditunjukkan oleh (Kurniati et al., 2018) yang menggunakan website untuk usaha ekonomi simpan pinjam. Dengan adanya website, segala kerumitan manual dapat diselesaikan dengan baik.

(Mas’ud, 2017) dalam papernya menjelaskan bahwa salah satu solusi untuk permasalahan promosi adalah dengan pemanfaatan teknologi informasi, antara lain website maupun aplikasi berbasis smartphone. Dengan penggunaan teknologi informasi, penjualan produk UMKM di kota pasuruan dapat meningkat secara signifikan. Hal ini dapat berlaku juga untuk promosi pada aspek yang lain, seperti promosi pada sebuah sekolah maupun instansi pendidikan. 
Pembuatan website dapat dilakukan dengan berbagai tahapan maupun cara, salah satunya yang dipresentasikan oleh (Izzah \& Kusuma, 2016), yaitu melalui tahapan persiapan, analisis kebutuhan, pembuatan desain, implementasi, dan pembuatan laporan. Setelah website dibuat, langkah penting selanjutnya adalah pelatihan atau pemaparan kepada subjek. Pelatihan memegang peranan penting dalam pengembangan sebuah teknologi, karena dengan adanya pelatihan, subjek yang tersebut dapat mengimplementasikan teknologi yang telah dibuat (Santoso et al., 2019).

Dengan adanya website informasi, pihak sekolah dapat memberikan informasi secara luas kepada publik mengenai tata cara pendaftaran, info PPDB maupun keadaan sekolah (Kurniawan, 2018). Selain itu, pihak sekolah juga dapat memberikan informasi kepada siswa-siswa sekolahnya maupun wali murid mengenai kegiatan-kegiatan di sekolah secara lebih efektif dan efisien, karena siswa hanya perlu membuka website sekolah dengan koneksi internet menggunakan handphone, tablet maupun laptop pribadi masing-masing. Dengan adanya website, maka pihak sekolah dapat terhubung secara lebih mudah dengan pihak di luar sekolah. Secara khusus, metode yang dilakukan pada kegiatan ini adalah Simulasi Ipteks, yaitu membuat sebuah aplikasi berupa website untuk sekolah.

Langkah-langkah yang dilakukan dalam menyelesaikan kegiatan ini dilakukan secara bertahap sebagai berikut :

\section{Need Assessment}

Langkah pertama yang harus dilakukan pada sebuah permasalahan adalah melakukan analisis terhadap kebutuhan (Kurniawan \& Barokah, 2020). Pada langkah ini dilakukan analisis terhadap situasi dan kebutuhan pada mitra. Metode yang dilakukan adalah dengan FGD (Focus Discussion Group) dengan kepala sekolah maupun guru untuk mengidentifikasi kebutuhan dari sekolah. Dari permasalahan yang muncul, dilakukan analisis lebih lanjut mengenai solusi yang ditawarkan, yaitu website informasi sekolah SMP N 2 Kalimanah.

\section{Implementasi Aplikasi}

Pada langkah ini, dibuatlah sebuah aplikasi, yaitu website informasi sekolah menggunakan wordpress serta database MySQL dengan konsep Relational Database. Website ini ditempatkan di server host internet, sehingga dapat diakses oleh pengguna dimanapun dan kapanpun, asalkan pengguna tersebut terhubung dengan internet. Penempatan aplikasi pada server host internet membuat aplikasi dapat dipergunakan tanpa terbatas oleh tools yang harus terletak di tempat tertentu.

\section{Pemaparan Aplikasi dan Pelatihan Ke Mitra}

Pada langkah ini, website informasi sekolah yang telah dibuat dapat dipresentasikan kepada guru dan staf SMP N 2 Kalimanah yang diberikan tanggung jawab oleh kepala sekolah. Presentasi aplikasi ini dilakukan dalam bentuk pelatihan dengan harapan guru-guru yang mengikuti pelatihan ini dapat menggunakan website dengan baik dan benar. Guru yang mengikuti pelatihan dapat dijadikan sebagai admin website tersebut, sehingga guru tersebut dapat melakukan update informasi, promosi serta menyebarkan berita maupun kegiatankegiatan sekolah dengan lebih baik.

\section{Simulasi Aplikasi dan Pengujian}

Pada langkah ini, guru yang menjadi admin website sekolah di SMP N 2 Kalimanah dapat melakukan update data, post informasi maupun berita serta kegiatan-kegiatan yang 
dilakukan oleh sekolah. Pada tahap ini juga dilakukan pengujian berupa User Acceptance Test untuk mengetahui preferensi pengguna (Al Irsyadi et al., 2020), yaitu guru di SMP N 2 Kalimanah terhadap website tersebut.

Pada tahap terakhir ini, juga dilakukan perawatan apabila terjadi kesalahan (error) serta ada perbaikan terhadap aplikasi. Pada tahap ini pula, dilakukan tindak lanjut mengenai pelatihan kepada guru di SMP N 2 Kalimanah, sehingga apabila guru yang mengikuti pelatihan tidak berada di sekolah, dapat digantikan oleh guru lain yang mengerti tentang website informasi sekolah tersebut.

\section{HASIL DAN PEMBAHASAN}

Pada bagian ini dibahas mengenai implementasi dari website informasi sekolah di SMP N 2 Kalimanah, pemaparan kepada mitra serta pengujian yang telah dilakukan.

\section{Implementasi Website}

Berdasarkan hasil analisis yang telah dilakukan bersama dengan kepala sekolah dan tim IT SMP N 2 Kalimanah, dibuatlah sebuah website informasi sekolah yang beralamat di https://smpn2kalimanah.sch.id. Website ini dibangun menggunakan Content Management Systems (CMS) Wordpress dengan theme yang telah dimodifikasi. Pemilihan Wordpress sebagai CMS yang digunakan karena Wordpress relative cepat untuk diimplementasikan serta memiliki user interface yang mudah untuk digunakan oleh orang awam. Selain itu, Wordpress memberikan fitur yang lengkap untuk sebuah portal maupun website informasi. Hal ini menjadikan Wordpress sebagai layanan CMS yang tepat untuk diimplementasikan di SMP N 2 Kalimanah.

Pembangunan website SMP N 2 Kalimanah membutuhkan waktu selama 1 bulan termasuk dengan pengisian konten yang telah dikonsultasikan kepada pihak sekolah terlebih dahulu. Gambar 3 menunjukkan tampilan utama atau halaman beranda dari website informasi sekolah di SMP N 2 Kalimanah yang beralamat di https://smpn2kalimanah.sch.id.

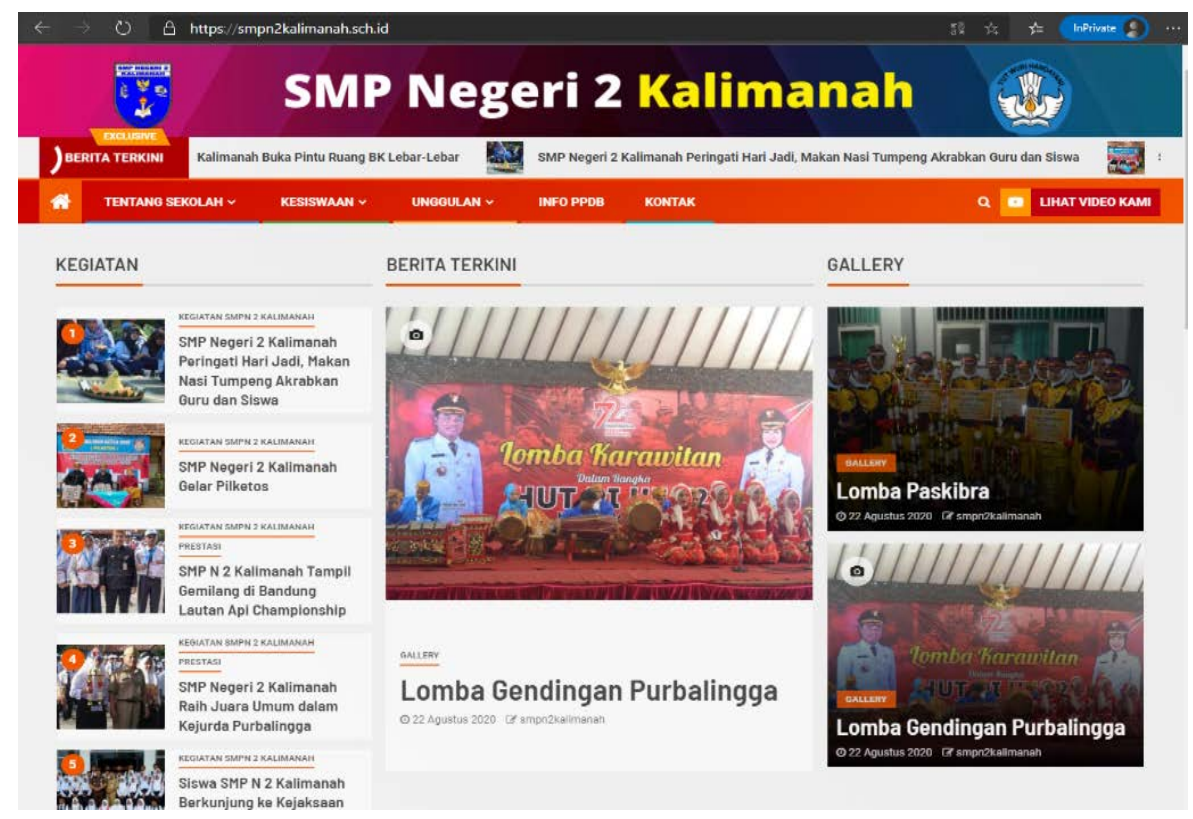




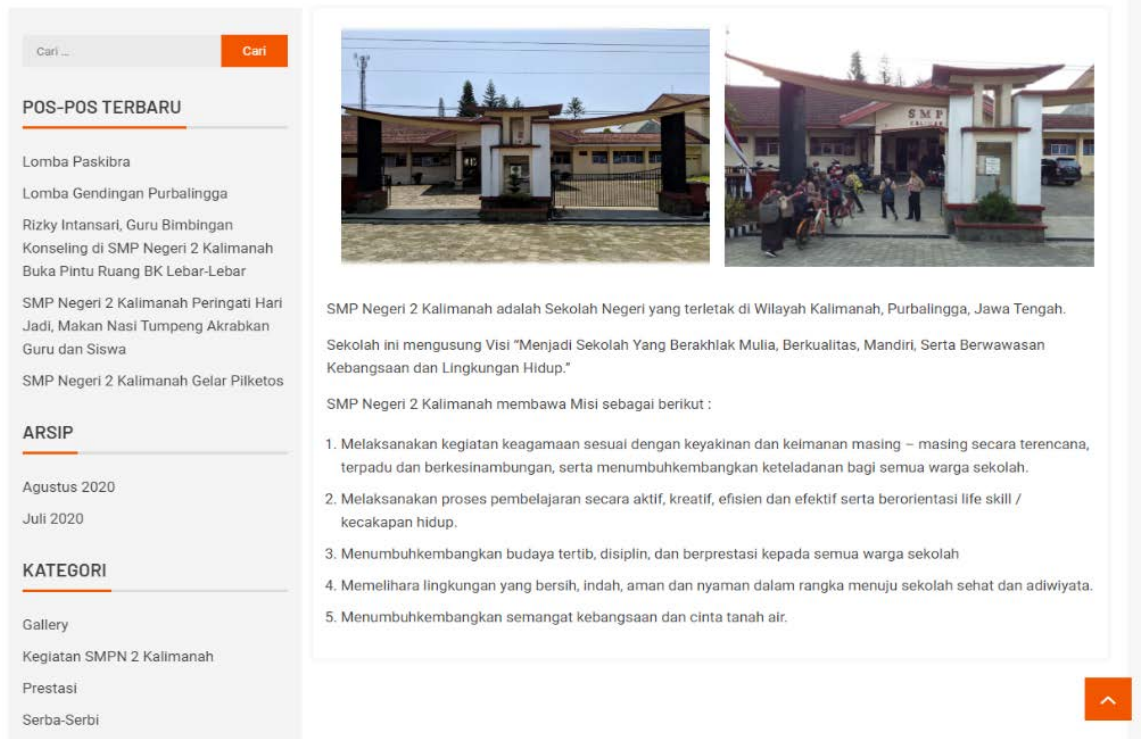

Gambar 3. Halaman Utama Website SMP N 2 Kalimanah

Pada halaman utama, terbagi menjadi beberapa bagian, yaitu menu utama di sebelah atas yang terdiri dari “Tentang Sekolah”, “Kesiswaan”, “Unggulan”, “Info PPDB” dan "Kontak". Pada menu Tentang Sekolah terdapat sub menu yang berisi "Visi dan Misi Sekolah”, "Struktur Organisasi”, “Guru’ dan "Staf dan Tata Usaha”. Pada menu Kesiswaan terdapat sub menu yang berisi "Kegiatan Ekstrakurikuler" dan "Pengumuman Siswa", sedangkan pada menu Unggulan, terdapat sub menu "Prestasi Sekolah", "Fasilitas", dan "Program Penegakan Disiplin”. Setiap sub menu tersebut berisi informasi-informasi tentang SMP N 2 Kalimanah. Sebagai contoh, gambar 4 menunjukkan sub menu "kontak” di website yang berisi kontak, alamat, telpon, email serta peta dari SMP N 2 Kalimanah.

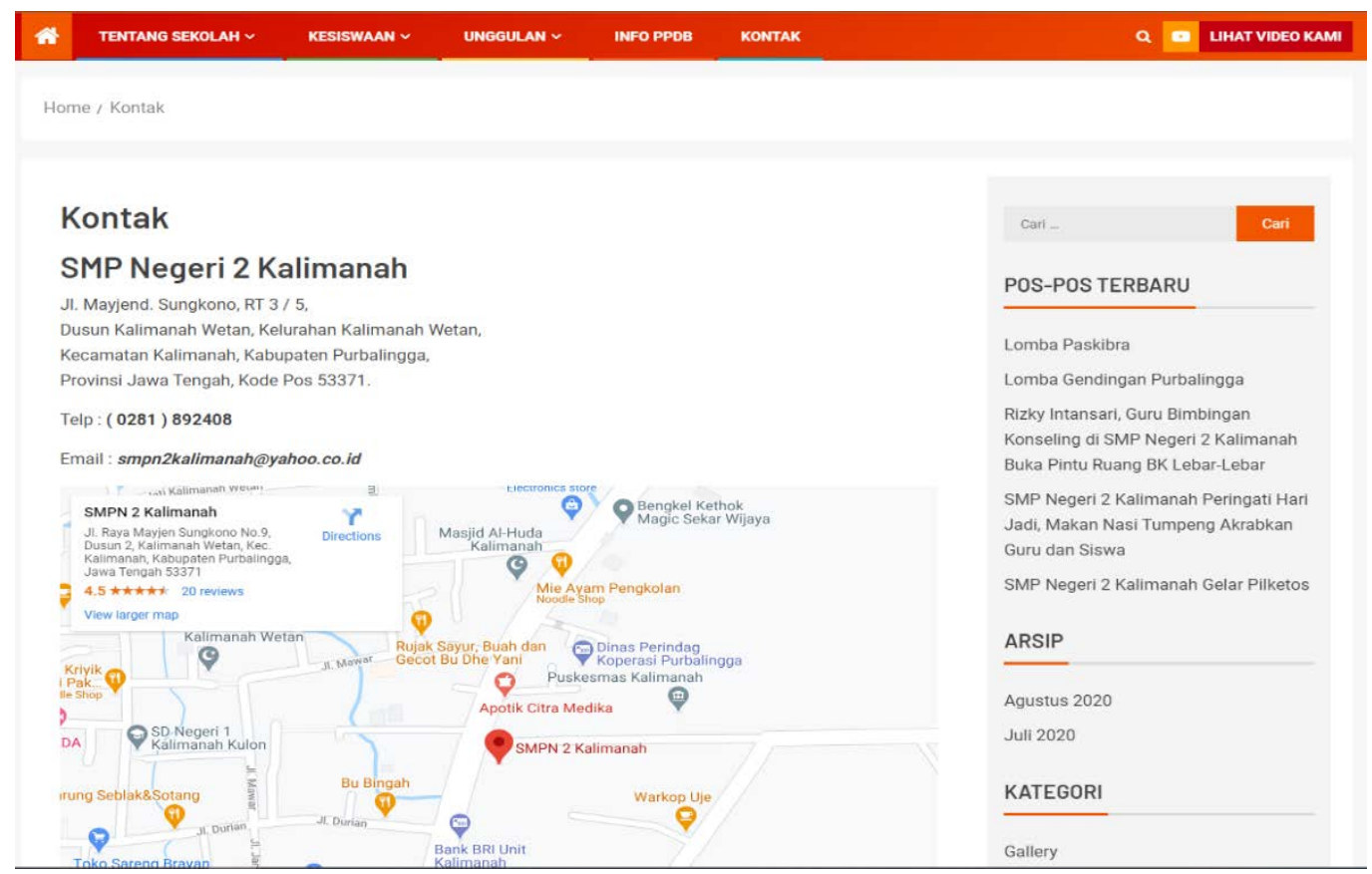

Gambar 4. Halaman Menu Kontak 
Selain menu, terdapat juga 3 blok di bagian beranda website. Blok sebelah kiri berisi kegiatan-kegiatan di SMP N 2 Kalimanah, blok tengah berisi semua berita terbaru dari website, dan blok kanan berisi gallery foto-foto tentang SMP N 2 Kalimanah. Secara keseluruhan, website ini dapat menampilkan segala hal terkini tentang sekolah kepada masyarakat luas. Gambar 5 dapat menunjukkan tampilan untuk berita yang di post pada website SMP N 2 Kalimanah.

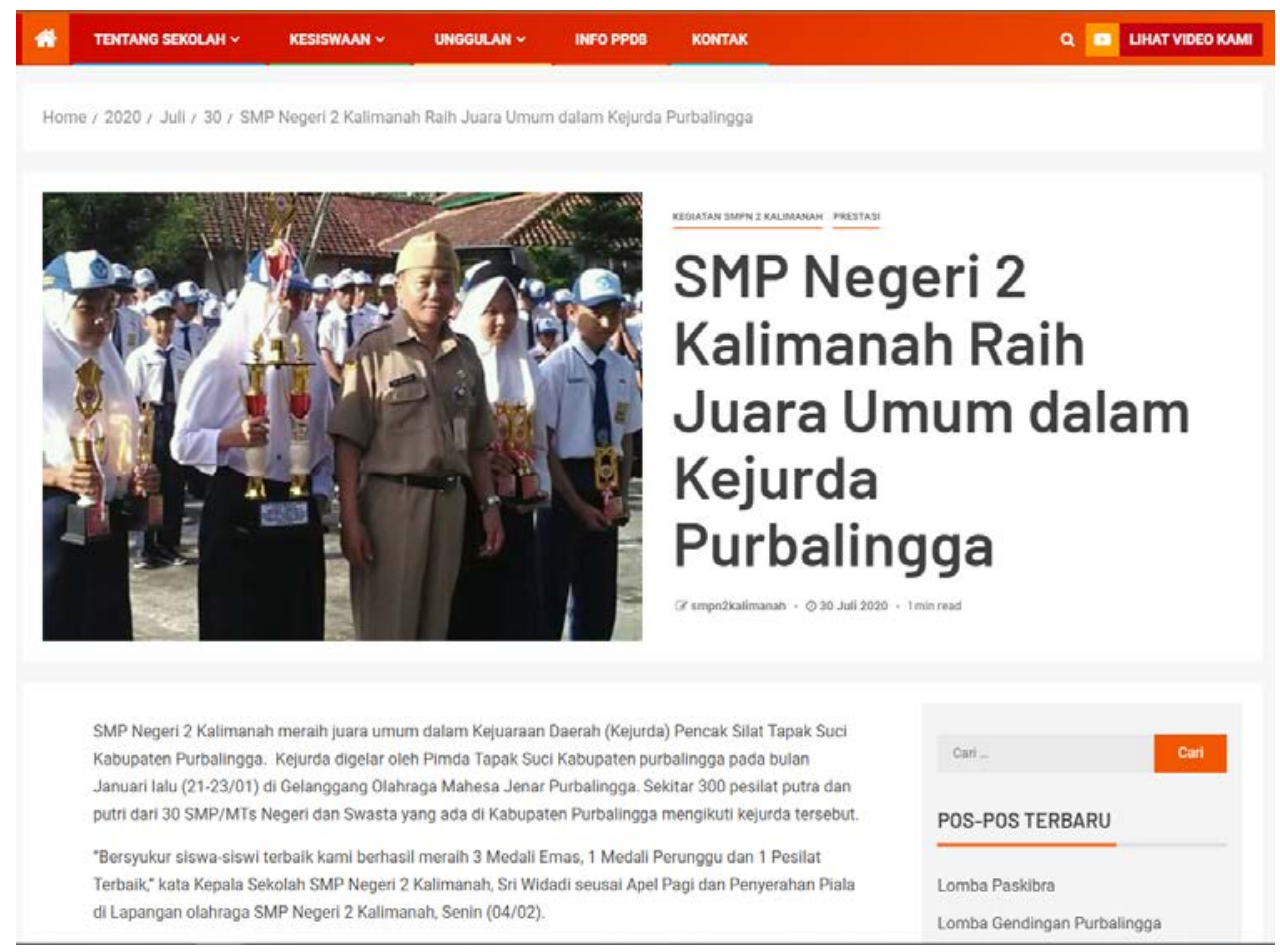

Gambar 5. Halaman Berita

Bagi guru maupun admin dari pihak sekolah, dapat masuk ke bagian Admin dengan memasukkan username dan password. Tampilan halaman admin dapat ditunjukkan oleh gambar 6 .

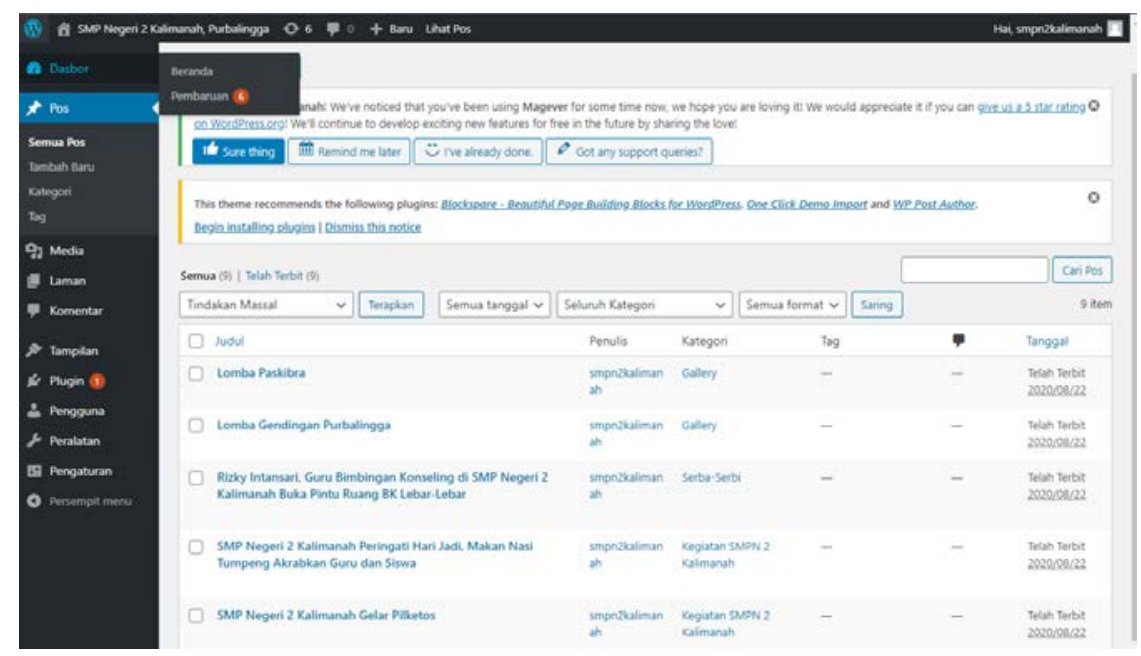

Gambar 6. Halaman Admin 
Pada halaman admin, dapat digunakan untuk menambah maupun mengubah isi dari menu-menu yang ada pada halaman website. Selain itu, admin juga dapat menambah, mengubah maupun menghapus berita-berita yang ingin ditampilkan di website. Fitur yang lain pada halaman admin adalah kemampuan untuk mengatur komentar, pengaturan menu dan tampilan serta pengaturan foto maupun seluruh media di website.

\section{Pemaparan Aplikasi dan Pelatihan kepada Mitra}

Tahap selanjutnya setelah website informasi SMP Negeri 2 Kalimanah selesai dibangun, kemudian diadakan sebuah pertemuan untuk membahas fitur-fitur dari website tersebut serta pelatihan kepada guru yang nantinya menjadi administrator untuk mengurusi website tersebut. Pelatihan diperlukan untuk transfer ilmu dari satu pihak ke pihak yang lainnya (Kurniawan, 2017). Kegiatan pendampingan dilaksanakan pada hari Rabu, tanggal 19 Agustus 2020. Kegiatan tersebut dilakukan secara online menggunakan aplikasi GoogleMeet dikarenakan kondisi pandemic Covid-19 yang tidak memungkinkan untuk pertemuan secara langsung. Pelatihan dihadiri oleh 10 orang guru SMP N 2 Kalimanah secara online.

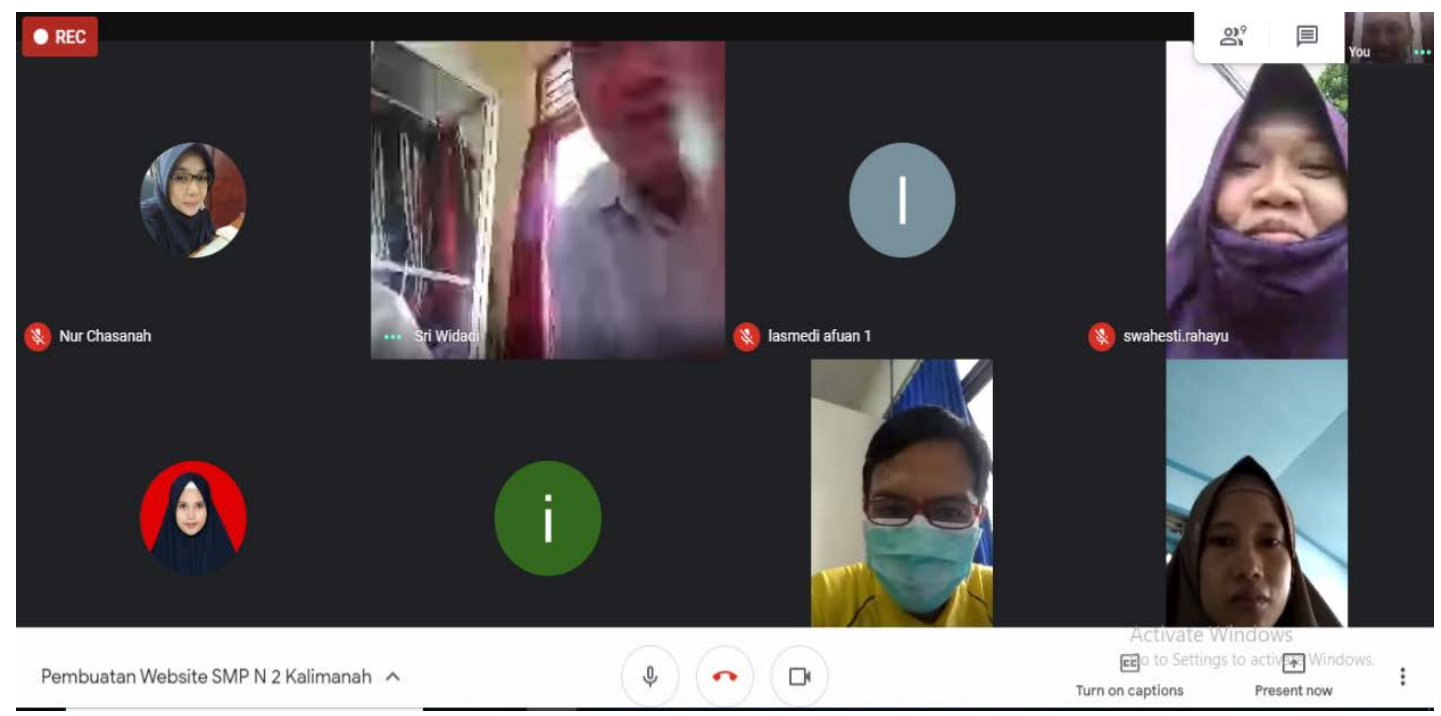

Gambar 7. Pelatihan Website SMP N 2 Kalimanah Secara Online

Metode yang digunakan dalam pemaparan tersebut adalah pelatihan serta tanya jawab secara langsung. Trainer menjelaskan mengenai cara menggunakan website beserta cara pengaturan seluruh konten dari website. Setelah itu, peserta diminta untuk mencoba mempraktekkan secara langsung setiap menu dan fungsionalitas yang telah diajarkan. Alokasi waktu untuk kegiatan pendampingan ini disajikan dalam tabel 1.

Tabel 1. Alokasi Waktu Untuk Kegiatan Pendampingan

\begin{tabular}{lc}
\hline \multicolumn{1}{c}{ Kegiatan } & Alokasi \\
& Waktu \\
\hline Pembukaan & 5 Menit \\
Sesi 1: Pelatihan Menu Website Informasi SMP N 2 Kalimanah & 90 Menit \\
Sesi 2: Sesi Tanya Jawab dan Saran Pengembangan Website & 20 Menit \\
Penutupan & 5 Menit \\
\hline
\end{tabular}


Dengan adanya pelatihan tersebut, maka guru yang menjadi administrator dari website informasi sekolah akan mengetahui setiap fitur, menu, serta cara penggunaan dari website tersebut.

\section{Pengujian}

Setelah implementasi dan pelatihan dilakukan, tahapan terakhir adalah pengujian pengguna terhadap website informasi SMP N 2 Kalimanah. Pengujian aplikasi kepada pengguna adalah tahapan yang penting karena dengan pengujian tersebut, dapat diketahui respon pengguna terhadap aplikasi yang dibangun. Pengujian yang dilakukan adalah User Acceptance Test (Irsyadi et al., 2019) untuk menguji preferensi pengguna terhadap website yang telah dibangun. Kepada 10 orang responden yang merupakan pengguna dari website, diberikan pertanyaan berupa kuesioner untuk diisi. Daftar pertanyaan pada kuesioner tersebut antara lain:

1. P1: Apakah website SMP N 2 Kalimanah sudah dapat memberikan informasi mengenai hal-hal yang berkaitan dengan sekolah, berita serta kegiatan sekolah dengan baik?

2. P2: Apakah website SMP N 2 Kalimanah sudah dapat menjadi alat promosi yang lebih baik daripada poster dan flier yang ada selama ini?

3. P3: Apakah website SMP N 2 Kalimanah sudah layak untuk digunakan?

Setelah dilakukan pengisian kuesioner oleh 10 orang responden, hasil pengujian tersebut dapat ditunjukkan oleh tabel 2.

Tabel 2. Hasil Pengujian User Acceptance Test

\begin{tabular}{ccclccc}
\hline \multirow{2}{*}{ Pertanyaan } & \multirow{2}{*}{ SS(4) } & S(3) & TS(2) & STS(1) & $\begin{array}{c}\text { Jumlah } \\
\text { Skor }\end{array}$ & Persentase \\
\hline P1 & 8 & 2 & 0 & 0 & 38 & $95 \%$ \\
P2 & 7 & 3 & 0 & 0 & 37 & $92,5 \%$ \\
P3 & 9 & 1 & 0 & 0 & 39 & $97,5 \%$ \\
& & Rata-Rata & & & 38 & $95 \%$ \\
\hline
\end{tabular}

Dari hasil pengujian diatas, dilakukan perhitungan dengan mengkalikan bobot (Sangat Setuju diberikan bobot 4, Setuju diberikan bobot 3, Tidak Setuju diberikan bobot 2 dan Sangat Tidak Setuju diberikan bobot 1) dengan jumlah responden. Setelah didapat jumlah skor, maka dicari persentase dengan membagi jumlah skor dengan nilai total maksimal skor yang bisa didapat (bobot $4 \times 10$ responden $=40$ ), sehingga didapat persentase dari setiap pertanyaan tersebut.

Dari hasil pengujian tersebut, didapat hasil bahwa 95\% responden menyatakan bahwa website SMP N 2 Kalimanah sudah dapat memberikan informasi mengenai hal-hal yang berkaitan dengan sekolah, berita serta kegiatan sekolah dengan baik. 92,5\% responden menyatakan bahwa website SMP N 2 Kalimanah sudah dapat menjadi alat promosi yang lebih baik daripada poster dan flier yang ada selama ini serta 97,5\% responden menyatakan bahwa website SMP N 2 Kalimanah sudah layak untuk digunakan. Rata-rata nilai secara keseluruhan adalah 95\%. Hal ini menunjukkan bahwa website SMP N 2 Kalimanah sudah dapat menyelesaikan permasalahan promosi serta penyampaian informasi yang sulit di SMP N 2 Kalimanah. 


\section{KESIMPULAN}

Berdasarkan kegiatan yang telah dilakukan, dapat diambil kesimpulan bahwa website informasi sekolah di SMP N 2 Kalimanah telah berhasil dibuat dengan menampilkan fitur berupa berita, foto maupun kegiatan-kegiatan di sekolah. Berdasarkan pengujian yang telah dilakukan, website informasi sekolah di SMP N 2 Kalimanah telah berhasil menyelesaikan permasalahan promosi serta penyampaian informasi di SMP N 2 Kalimanah. Kegiatan pengabdian selanjutnya yang dapat dilakukan untuk SMP N 2 Kalimanah adalah pendampingan berkelanjutan, baik pendampingan penulisan konten website berupa literasi media dan literasi berita, sehingga guru-guru yang diberikan tugas untuk mengisi website dapat mengelola website SMP N 2 Kalimanah dengan lebih baik maupun pendampingan pengelolaan website kepada admin dan guru-guru sekolah.

\section{UCAPAN TERIMA KASIH}

Terima kasih kami ucapkan kepada Lembaga Penelitian dan Pengabdian Masyarakat Universitas Jenderal Soedirman yang telah mendanai kegiatan ini, dan pihak SMP Negeri 2 Kalimanah yang telah memberikan bantuan selama kegiatan serta semua pihak yang telah membantu terlaksananya kegiatan ini.

\section{DAFTAR PUSTAKA}

Al Irsyadi, F. Y., Priambadha, A. P., \& Kurniawan, Y. I. (2020). Game Edukasi Bahasa Arab untuk Siswa Kelas IV di Sekolah Dasar Islam Terpadu Nahdlatul Ulama Cepgo. Jurnal Manajemen Informatika (JAMIKA), 10(1), 55-66. https://doi.org/10.34010/jamika.v10i1

Azizah, N., \& Saputro, H. (2020). Implementasi Official Website Sekolah untuk Peningkatan Mutu Layanan pada SMA Hidayatul Mustafidin Dawe Kudus. E-DIMAS : Jurnal Pengabdian Kepada Masyarakat, 11(2), 139-143.

Haris, A. S., Fadli, S., \& Tantoni, A. (2019). Sistem Manajemen Lembaga Penelitian Dan Pengabdian Kepada Masyarakat Berbasis Web. Jurnal Manajemen Informatika Dan Sistem Informasi, 2(1), 28-35. https://doi.org/10.36595/misi.v2i1.76

Irsyadi, F. Y. Al, Supriyadi, S., \& Kurniawan, Y. I. (2019). Interactive educational animal identification game for primary schoolchildren with intellectual disability. International Journal of Advanced Trends in Computer Science and Engineering, 8(6), 3058-3064. https://doi.org/10.30534/ijatcse/2019/64862019

Izzah, A., \& Kusuma, S. ferdiana. (2016). Pembuatan Katalog Online Layanan Jasa Berbasis Web Sebagai Media Periklanan Penyedia Layanan Jasa. Jurnal Pengabdian Masyarakat J-DINAMIKA, 1(2), 108-115.

Kurniati, R., Ratnawati, F., \& Putra, F. P. (2018). Penerapan Aplikasi Rencana Angsuran Pembayaran Pada Usaha Ekonomi Desa Simpan Pinjam Sungai Alam Berbasis Web. Panrita Abdi, 2(2), 165-173.

Kurniawan, Y. I. (2017). Pelatihan Aplikasi Pengukuran Minat Kejuruan Siswa Bagi Guru 
Sekolah Menengah Kejuruan (SMK) Se-Jawa Tengah. Warta LPM, 19(2), 149-155. https://doi.org/10.23917/warta.v19i2.2224

Kurniawan, Y. I. (2018). Pembangunan Website Informasi Sekolah Di Sma Negeri Kerjo , Karanganyar. Jurnal Pengabdian Kepada Masyarakat (J-ABDIPAMAS), 2(1), 71-84.

Kurniawan, Y. I., \& Barokah, T. I. (2020). Klasifikasi Penentuan Pengajuan Kartu Kredit Menggunakan K-Nearest Neighbor. Jurnal Ilmiah Matrik, 22(1), 73-82. https://doi.org/10.33557/jurnalmatrik.v22i1.843

Lubis, Y. F. A., Khairani, M., \& Wulan, N. (2020). Pembangunan Website Sekolah dan Penerimaan Siswa Baru Pada Sekolah Nur Nur Azizi Berbasis Content Management System (CMS). TRIDARMA : Pengabdian Kepada Masyarakat (PkM), 3(1), 117-121.

Mas'ud, M. (2017). Pemanfaatan Teknologi Sistem Informasi untuk Meningkatkan Penjualan Hasil Produk UMKM Logam di Kota Pasuruan. Engagement: Jurnal Pengabdian Kepada Masyarakat, 1(2), 185-197. https://doi.org/10.29062/engagement.v1i2.14

Santoso, H. B., Delima, R., \& Wibowo, A. (2019). Pelatihan Pengembangan Web Profil Desa bagi Aparatur Pemerintah Desa. E-DIMAS: Jurnal Pengabdian Kepada Masyarakat, 10(1), 41-48.

Sholikat, I., Rosyadi, H. E., \& Putri, D. M. (2019). Rancang Bangun Website yang Berorientasi Video Sebagai Sarana Media Informasi di SMK YP 17-2 Malang. ILKOMNIKA : Journal of Computer Science and Applied Informatics, 1(1), 15-23.

Tentua, M. N., \& Saputra, N. (2020). Pengembangan Dan Pendampingan Website Tk Aba An-Nur. Jurnal Berdaya Mandiri, 2(1), 225-237.

Wiryotinoyo, M., Budiyono, H., Akhyaruddin, Setyonegoro, A., \& Priyanto. (2020). Pemanfaatan Website sebagai Media Promosi dan Sumber Belajar di Sekolah Menengah. Jurnal Abdi Pendidikan, 01(1), 1-5.

Wulandari, \& Dewi, Y. P. (2019). Pembuatan Website Profile Sekolah Berbasis Php Pada Tpq Hifdzillah Jakarta Selatan. Ikraith-Abdimas, 2(3), 119-122. 